\title{
Correction to: Deciphering cellular transcriptional alterations in Alzheimer's disease brains
}

Xue Wang ${ }^{1 *}$, Mariet Allen², Shaoyu Li ${ }^{3}$, Zachary S. Quicksall' ${ }^{1}$, Tulsi A. Patel ${ }^{2}$, Troy P. Carnwath², Joseph S. Reddy ${ }^{1}$, Minerva M. Carrasquillo², Sarah J. Lincoln², Thuy T. Nguyen², Kimberly G. Malphrus², Dennis W. Dickson², Julia E. Crook', Yan W. Asmann ${ }^{1}$ and Nilüfer Ertekin-Taner ${ }^{2,4^{*}}$

\section{Correction to: Mol Neurodegeneration (2020) 15:38 https://doi.org/10.1186/s13024-020-00392-6}

After publication of this article [1], the author reported that Figure S8 in Additional File 1 contains tracks of insertion, which should have been accepted. The updated Additional File 1 is shown in the Additional File section below.

\section{Supplementary information}

Supplementary information accompanies this paper at https://doi.org/10. 1186/s13024-020-00403-6.

Additional file 1.

\section{Author details}

'Department of Health Sciences Research, Mayo Clinic Florida, Jacksonville, FL, USA. ${ }^{2}$ Department of Neuroscience, Mayo Clinic Florida, Jacksonville, FL, USA. ${ }^{3}$ Department of Mathematics and Statistics, University of North Carolina at Charlotte, Charlotte, NC, USA. ${ }^{4}$ Department of Neurology, Mayo Clinic

Florida, Jacksonville, FL, USA.

Published online: 15 September 2020

\section{Reference}

1. Wang X, Allen M, Li S, et al. Deciphering cellular transcriptional alterations in Alzheimer's disease brains. Mol Neurodegeneration. 2020;15:38 https://doi. org/10.1186/s13024-020-00392-6.

\footnotetext{
The original article can be found online at https://doi.org/10.1186/s13024020-00392-6.

*Correspondence: Wang.Xue@mayo.edu; Taner.Nilufer@mayo.edu

'Department of Health Sciences Research, Mayo Clinic Florida, Jacksonville,

$\mathrm{FL}, \mathrm{USA}$

2Department of Neuroscience, Mayo Clinic Florida, Jacksonville, FL, USA

Full list of author information is available at the end of the article
}

C C The Author(s). 2020 Open Access This article is licensed under a Creative Commons Attribution 4.0 International License, which permits use, sharing, adaptation, distribution and reproduction in any medium or format, as long as you give appropriate credit to the original author(s) and the source, provide a link to the Creative Commons licence, and indicate if changes were made. The images or other third party material in this article are included in the article's Creative Commons licence, unless indicated otherwise in a credit line to the material. If material is not included in the article's Creative Commons licence and your intended use is not permitted by statutory regulation or exceeds the permitted use, you will need to obtain permission directly from the copyright holder. To view a copy of this licence, visit http://creativecommons.org/licenses/by/4.0/. The Creative Commons Public Domain Dedication waiver (http://creativecommons.org/publicdomain/zero/1.0/) applies to the data made available in this article, unless otherwise stated in a credit line to the data. 